\title{
Influence of Taking L-Arg on Immune Function of Basketball Players
}

\author{
Yang Wen-xian*
}

College of Physical Education of Henan Normal University, Xinxiang, P.R. China

\begin{abstract}
Objective: Explore the influence of L-Arg on immune function of basketball players. Method: Select 20 basketball players of the school as the objects of study, and randomly divide them into control group and experimental group, with 10 students for each group. The control group takes the same amount of placebo, while the experimental group takes L-Arg capsule, three times a day, with the dose of $15 \mathrm{~g}$ for each time. The experimental period is two weeks. Observe the influence on immune functions of two groups of players after the experimental period. Result: After a lot of exercise of players in two groups, C3 value sees obvious change, with obvious rise for the experimental group, and obvious decline for control group. The comparative results show significant difference ( $\mathrm{p}$ 0.05). For C4 value, experimental group shows unobvious change before and after the experiment, while control group shows obvious change. But there is no statistical significance ( $\mathrm{p}$ 0.05). After intensive exercise, IL-2 changes significantly and S-IL-2R concentration declines in serum of the basketball player taking L-Arg, which shows significant difference compared with that before exercise ( $p$ 0.05). TNF- $\alpha$ shows unobvious change in experimental group and control group. Conclusion: Taking L-Arg contributes to improving players' immune functions, and plays an important role in maintaining the stability of players' immune functions.
\end{abstract}

Keywords: L-Arg, basketball player, immune function.

\section{INTRODUCTION}

Through investigation and study on the relevant pathology, it can be concluded that appropriate immune function training contributes to the improvement in players' physique [1], but excessive training will reduce players' immunity, lead to the rise in chances of infection and even increase players' feeling of fatigue after training and competition due to the effect of other factors. L-Arg can effectively inhibit cell division and promote wound healing, timely eliminate oxygen [2-3]. Also it has certain immune functions and can secrete more hormone. Players' immune functions can be effectively improved by supplementing L-amino acids. Based on the impact of L-Arg on immune functions, the study will select 20 basketball players as objects of study to conduct a detailed analysis on impact of taking L-Arg on basketball players' immune function [4]. The specific report is as follows.

\section{MATERIAL AND METHODS}

\subsection{Objects}

Select 20 basketball players as the object of the study, and randomly divide them into control group and experimental group, with 10 students for each group, totaling 6 level-I players and 14 level-II players. All objects of study conform to the standard, not suffering from serious metabolic disease and other immune system disease [5]. Also, the subjects to the standard, not suffering from serious metabolic disease and other immune system disease. Also, the subjects to the standard, not suffering from serious metabolic disease and other immune system disease [6,7]. Also, the subjects do not suffer from any disease before experiment and voluntarily join the experiment. The basic information of players is seen in Table $\mathbf{1}$.

\subsection{Experimental Design}

In this study, 20 basketball players are divided into two groups, control group and experimental group, with 10 players for each group. The players in control group take L-Arg capsule three times per day, with the dose of $15 \mathrm{~g}$ each time. L-Arg is L-Arginine dietary supplements produced by Jarrow Formulas (the U.S.), and has passed FDA certification (Product Number: 15036, Product Code: ARG). The players in control group take the same amount of placebo, which is the capsule of the same shape. The experimental period for the two groups is two weeks, during which all players are given intensive training including speed training and skill training each week, taking one month as the time limit. In order to ensure the rationality of sports design, the way and category of training shall be defined in practice. As basketball involves various technical programs, the experiment shall be made according to the established design method, and physical training shall focus on conventional content. Also, the basketball players shall have a certain understanding of the sports content in advance. In the process of exercise, in the afternoon, three hours should be used for simulated competitions and physical quality training, and heart rate during physical training and skill training shall be respectively controlled at around 180 times/min and 170 times/min. During the experiment, apart from the normal diets and L-Arg capsules and placebos, the subjects shall not 
Table 1. Analysis on basic information of 20 players.

\begin{tabular}{|c|c|c|c|c|c|}
\hline Group & $\begin{array}{c}\text { Case } \\
\text { number }\end{array}$ & $\begin{array}{c}\text { Age (years } \\
\text { old) }\end{array}$ & $\begin{array}{c}\text { Height } \\
\mathbf{( c m )}\end{array}$ & $\begin{array}{c}\text { Weight } \\
\mathbf{( k g )}\end{array}$ & $\begin{array}{c}\text { Training } \\
\text { time } \\
\text { (year) }\end{array}$ \\
\hline \hline $\begin{array}{c}\text { Control } \\
\text { group }\end{array}$ & 10 & $18.23 \pm 2.24$ & $182.3 \pm 3.25$ & $75.1 \pm 3.5$ & $4.25 \pm 2.1$ \\
\hline $\begin{array}{c}\text { Experimental } \\
\text { group }\end{array}$ & 10 & $19.24 \pm 2.4$ & $182.2 \pm 3.56$ & $74.25 \pm 3.2$ & $4.54 \pm 3.2$ \\
\hline
\end{tabular}

use other dietary supplements. To improve the trainees' willpower, various training activities shall be carried out in practice, and also systematical analysis shall be made on design procedures to push the original limitations of design programs, so as to make a reasonable way and program mode in combination with players' situation and give them timely training. The specific arrangement can be seen in Table 2:

Except the conventional training, simulated competitions shall be appropriately carried out. As basketball players need to gather experience to improve their basketball skills, a lot of experiments shall be done. Heart rate shall be controlled at 170-180 times/min during physical training. During the experiment, all players shall not take other health care products except the normal diets, L-Arg capsules and placebo.

\subsection{Measurement Index and Method}

Draw the subjects' venous blood of $5 \mathrm{ml}$ before the experiment and after two-week training, and take supernatant liquid after centrifugation. Prepare serum with vacuum blood tube and place it in refrigerator below $20^{\circ} \mathrm{C}$, and then measure the indexes through IL-2, S-IL-2R and iTNF- $\alpha$. The specific measurement indexes include interleukin (IL-2), soluble interleukin -2 receptor (S-IL-2R) and tumor necrosis factor
(TNF- $\alpha$ ), and the measurement method is ELISA double antibody sandwich method. The kit is provided by the U.S. Genzyme. For the measurement of $\mathrm{C} 3$ and $\mathrm{C} 4$ content, immunoturbidimetry shall be adopted, with Italian F7-2 fullautomatic biochemical analyzer. The kit is provided by Sichuan Maccura Biotechnology Co., Ltd.

\subsection{Statistical Analysis}

During this study, statistics software SPSS20.0 is adopted to handle the statistical data. T-test is adopted for measurement data, and X2-test is adopted for counting data. The difference $(\mathrm{P}<0.05)$ is of statistical significance.

\section{RESULTS}

\subsection{Influence of Taking L-Arg on C3 and C4 of Basket- ball Players}

Influence of taking L-Arg on $\mathrm{C} 3$ and $\mathrm{C} 4$ of basketball players: After a lot of exercise, C3 value sees obvious change, with obvious rise for the experimental group, and obvious decline for control group. The comparative results show significant difference $(\mathrm{p}<0.05)$. For $\mathrm{C} 4$ value, experimental group shows unobvious change before and after the experiment, while control group shows obvious change. But

Table 2. Analysis on weekly training content.

\begin{tabular}{|c|c|c|c|c|c|c|}
\hline Monday & Tuesday & Wednesday & Thursday & Friday & Saturday & Sunday \\
\hline \hline $\begin{array}{c}\text { Speed } \\
\text { training }\end{array}$ & $\begin{array}{c}\text { Speed } \\
\text { training }\end{array}$ & $\begin{array}{c}\text { Skill train- } \\
\text { ing }\end{array}$ & Adjustment & $\begin{array}{c}\text { Speed } \\
\text { training }\end{array}$ & $\begin{array}{c}\text { Skill } \\
\text { training }\end{array}$ & $\begin{array}{c}\text { Adjustment } \\
\text { and rest }\end{array}$ \\
\hline & $\begin{array}{c}\text { Skill } \\
\text { training }\end{array}$ & & $\begin{array}{c}\text { Skill } \\
\text { training }\end{array}$ & & \\
\hline
\end{tabular}

Table 3. Comparative analysis on $\mathrm{C} 3$ and $\mathrm{C} 4$ of 20 players before and after experiment.

\begin{tabular}{|c|c|c|c|c|}
\hline \multirow{2}{*}{ Group } & \multicolumn{2}{|c|}{ C3 (mg/dl) } & \multicolumn{2}{c|}{ C4 (mg/dl) } \\
\cline { 2 - 5 } & $\begin{array}{c}\text { Before ex- } \\
\text { periment }\end{array}$ & $\begin{array}{c}\text { After ex- } \\
\text { periment }\end{array}$ & $\begin{array}{c}\text { Before } \\
\text { experiment }\end{array}$ & $\begin{array}{c}\text { After } \\
\text { experi- } \\
\text { ment }\end{array}$ \\
\hline \hline $\begin{array}{c}\text { Experiment } \\
\text { group }\end{array}$ & $110.25 \pm 14.25$ & $126.89 \pm 19.25$ & $23.25 \pm 7.25$ & $23.56 \pm 5.15$ \\
\hline $\begin{array}{c}\text { Control } \\
\text { group }\end{array}$ & $115.26 \pm 14.56$ & $107.89 \pm 18.45$ & $26.56 \pm 6.45$ & $23.89 \pm 5.45$ \\
\hline
\end{tabular}


there is no statistical significance $(p>0.05)$. The specific comparative result is shown in Table $\mathbf{3}$ :

\subsection{Influence of Taking L-Arg on IL-2, S-IL-2R and TNF- $\alpha$ of Basketball Players}

Taking L-Arg has a certain influence on IL-2, S-IL-2R and TNF- $\alpha$ of players in practice. After intensive exercise, IL-2 changes significantly and S-IL-2R concentration declines in serum of the basketball player taking L-Arg, which shows significant difference compared with that before exercise $(\mathrm{p}<0.05)$. Influence of taking L-Arg on IL-2, S-IL-2R and TNF- $\alpha$ of basketball players: during two-week highvolume training, IL-2 rises significantly and S-IL-2R concentration sharply declines in serum of the basketball player taking L-Arg, which is of statistical significance compared with that before experiment $(\mathrm{P}<0.05)$. The control group shows unobvious change in concentration of IL-2 and S-IL$2 \mathrm{R}$ before and after experiment. After a large amount of exercise of the two groups, there is no significant change in concentration of TNF- $\alpha$. The comparative results can be seen in Table 4: Experimental group and control group show unobvious change in TNF- $\alpha$. The specific analysis results can be seen in Table 5 .

\section{DISCUSSION AND ANALYSIS}

\subsection{Influence of Taking L-Arg on Complement C3 and C4 of Players with High-volume Training}

Complement is a group of globulin with enzymatic activity in the blood serum of human and animals, and is related to the relevant immune system. The complement is connected with antigenic stimulation, so it becomes relatively stable substance in immunoreactions. The biological effect of complement system is bacteriolysis, sterilization and other effects of cells. C3 is an important part with more content in complement system, which involves two main activating ways and is of important physiological function. It is the core link of two main activating ways of complements and is of important biological function. Thus the study on $\mathrm{C} 3$ attaches more importance on the stability of complement system, which is of significant effect on maintaining the health of body. The study shows that, the control group shows a decline in serum complement $\mathrm{C} 3$ and $\mathrm{C} 4$ after high-volume training for two weeks, and the decline in $\mathrm{C} 3$ is of statistical significance, while the experimental group maintains a stable complement system by taking L-Arg, and keeps $\mathrm{C} 3$ and $\mathrm{C} 4$ at a normal range.

\subsection{Influence of Taking L-Arg on IL-2, S-IL-2R and TNF- $\alpha$ of Players with High-volume Training}

The requirement of L-Arg is amino acid, and L-Arg has various unique physiological and pharmacologic actions, and becomes the required amino acid under the condition of hunger, injury and disease. Besides, L-Arg is synthetic substance, and can generate urea and ornithine under the dual influence of body protein. Besides, ornithine will generate polyamine under the action of ornithine decarboxylase, and then further promote cell division and DNA replication, adjust cell cycle, and enhance the mitosis of lymphocyte. The study proves that IL-2 can independently generate growth hormone and insulin through relevant pharmacologic action, and then increase the weight of thymus and improve the number of T-lymphocyte and its proliferation reaction to PHA and ConA, so as to enhance the function of thymus. TNF- $\alpha$ is mainly generated by mononuclear macrophage activated by LPS, and itself has a certain biological effect, and it can prove that the excessive TNF- $\alpha$ has a certain relation with various diseases under the effect of biological factors.

After a lot of exercise, C3 value sees obvious change, with obvious rise for the experimental group, and obvious decline for control group. The comparative results show significant difference $(p<0.05)$. For $\mathrm{C} 4$ value, experimental group shows unobvious change before and after the experiment, while control group shows obvious change. But there

Table 4. Change in IL-2 and S-IL-2R before and after experiment.

\begin{tabular}{|c|c|c|c|c|}
\hline \multirow{2}{*}{ Group } & \multicolumn{2}{|c|}{ IL-2(pg/ml) } & \multicolumn{2}{c|}{ IL-2(pg/ml) } \\
\cline { 2 - 5 } & $\begin{array}{c}\text { Before } \\
\text { experiment }\end{array}$ & $\begin{array}{c}\text { After ex- } \\
\text { periment }\end{array}$ & $\begin{array}{c}\text { Before ex- } \\
\text { periment }\end{array}$ & $\begin{array}{c}\text { After ex- } \\
\text { periment }\end{array}$ \\
\hline \hline $\begin{array}{c}\text { Experimental } \\
\text { group }\end{array}$ & $60.14 \pm 23.54$ & $126.58 \pm 31.25$ & $\begin{array}{c}514.23 \pm \\
31.25\end{array}$ & $345.25 \pm 41.2$ \\
\hline $\begin{array}{c}\text { Control } \\
\text { group }\end{array}$ & $61.25 \pm 27.54$ & $78.56 \pm 30.25$ & $520.14 \pm 26.54$ & $518.4 \pm 42.5$ \\
\hline
\end{tabular}

Table 5. Change in TNF- $\alpha$ before and after experiment.

\begin{tabular}{|c|c|c|}
\hline \multirow{2}{*}{ Group } & \multicolumn{2}{|c|}{ TNF- $\boldsymbol{\alpha}(\mathbf{p g} / \mathbf{m l})$} \\
\cline { 2 - 3 } & Before experiment & After experiment \\
\hline \hline Experimental group & $32.1 \pm 12.1$ & $27.2 \pm 12.4$ \\
\hline Control group & $31.55 \pm 12.4$ & $28.4 \pm 12.5$ \\
\hline
\end{tabular}


is no statistical significance $(\mathrm{p}>0.05)$. It indicates that LArg has a certain effect in practice.

IL-2 is mainly generated by activated TH cell. It has a high affinity, can organically combine with IL-2 receptor and activate $T$ cell, and has a certain immune function as cell receptor. But restricted by other relevant factors, it results in significant increase in serum TNF- $\alpha$ and inhibition of TNF- $\alpha$ release induced by LPS. In this study, the players of experimental group after taking L-Arg see a lower respiratory tract infection (RTI) than that of control group during one-month high-volume training, which indicates that L-Arg plays an important role in improving basketball players' immunity and also contributes to ensuring players' physical fitness. Also, L-Arg can ensure the stability of C3 and C4 of players, and protect players' immunity by adjusting the effect of IL-2 receptor.

TNF- $\alpha$ is mainly generated by LPS-activated mononuclear macrophage. It has a wide range of biological activity. Currently, it has proved that excessive TNF- $\alpha$ is closely related to the development of many diseases. But little is done for study on relation between sports and TNF- $\alpha$. It is founded by the study that, after 20 players do exhaustive exercise for one hour, the serum TNF-A sees a significant increase, while LPS-induced TNF- $\alpha$ release is inhibited. The two groups do not see obvious change in TNF-A after twoweek high-volume training. The experimental group sees a lower respiratory tract infection (RTI) than that of control group during two-week high-volume training, indicating LArg can protect and maintain the immune functions of basketball players by keeping stability of players' complement C3 and C4 system and adjusting the function of IL-2 and receptor.

\section{CONCLUSION}

The study has made a detailed analysis on the influence of taking L-Arg on immune functions of basketball players. And practice proves that, the experimental group shows a more obvious contrast effect compared with control group, indicating that L-Arg has a certain influence on immune functions of basketball players. During the training, taking L-Arg can increase IL-2 and C3, and also significantly reduce S-IL-2R. As L-Arg is the direct precursor of nitric oxide, urea and ornithine as well as an important element of synthesis, L-Arg plays a crucial role in ensuring the normal immune functions and enhancing training results during players' training.

\section{CONFLICT OF INTEREST}

The authors confirm that this article content has no conflicts of interest.

\section{ACKNOWLEDGEMENT}

This work is supported by the Key Project of Guangxi Social Sciences, China (No.gxsk201424), the Education Science fund of the Education Department of Guangxi, China (No. 2014JGA268), and Guangxi Office for Education Sciences Planning, China (No. 2013C108).

\section{REFERENCES}

[1] Y. Teng, X. Li, Y. Gao, and X. Wang, "Research on influence of taking L-Arg on basketball players' Immune Functions" Journal of Shenyang Sport University, vol. 12, no.10, pp. 90-94, 2009.

[2] W. Sheng, "influence of lycium barbarum polysaccharide (LBP) on college students majoring in basketball" Journal of Xinxiang Medical University, vol. 19, no.10, pp. 200-203, 2011.

[3] W. Wan, and X. Hao, "Influence of exercise training on immune Function and immune regulation effect," Journal of Physical Education, vol. 20, no.10, pp. 300-302, 2012.

[4] Q. Liu, "Influence of Nutrition Intervention on Immune Function of Female Athletes of Martial Art Routine" Shanghai University of Sport, vol. 18, no.10, pp. 30-33, 2010.

[5] W. Han, "Research on Influence of Supplementing Lycium Barbarum Polysaccharide (LBP) on Some Immune Indexes of Mice with Heavy-load Exercise," Henan University, no.01, pp. 400-402, 2011.

[6] W. Zhang, "Influence of fleece-flower root capsule on immune functions of middle and long distance Youth Runners," Hubei Sports Science, no.04, pp. 490-492, 2014.

[7] W. Liu, "Experimental Study on Influence of Aerobics and L-Arg on Content of P-selectin and ICAM-1 in Artery of Mice with Highfat Diets," Soochow University, vol.13, no.01, pp. 290-293, 2014.

\footnotetext{
Received: June 10,2015 Revised: July 29, 2015 Accepted: August 15, 2015

(C) Yang Wen-xian; Licensee Bentham Open.

This is an open access article licensed under the terms of the (https://creativecommons.org/licenses/by/4.0/legalcode), which permits unrestricted, noncommercial use, distribution and reproduction in any medium, provided the work is properly cited.
} 